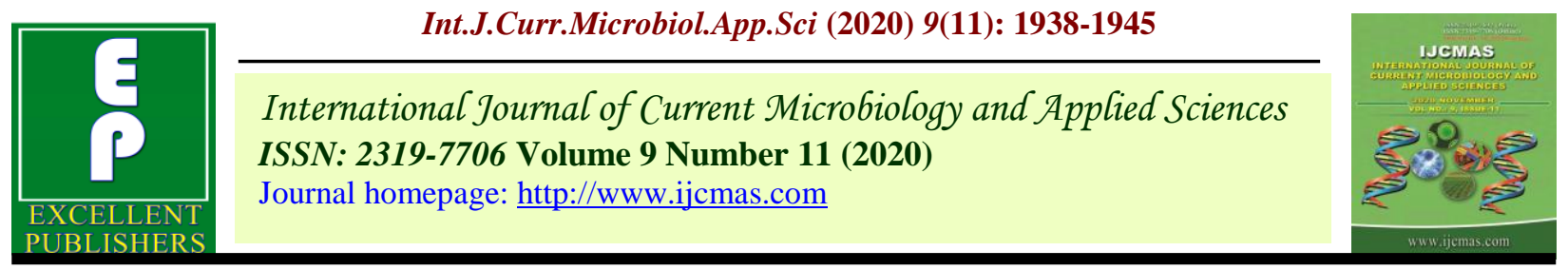

Original Research Article

https://doi.org/10.20546/ijcmas.2020.911.229

\title{
Molecular Detection of Bulb-Associated Potyviruses in Garlic and their Field Response
}

\author{
Kumar Aditya ${ }^{1 *}$, A.P. Bhagat ${ }^{1}$, Sangeeta Shree $^{2}$ and Mohammad Ansar ${ }^{1}$ \\ ${ }^{1}$ Department of Plant Pathology, ${ }^{2}$ Department of Horticulture (Vegetable \& Floriculture), \\ Bihar Agricultural University, Sabour, Bhagalpur(Bihar), 813210, India \\ *Corresponding author
}

\begin{tabular}{l}
\hline Ke y w o r d s \\
$\begin{array}{l}\text { Genotype, RT-PCR, } \\
\text { Potyvirus, Virus- } \\
\text { free garlic }\end{array}$ \\
\hline Article Info \\
$\begin{array}{l}\text { Accepted: } \\
\text { 15 October } 2020 \\
\text { Available Online: } \\
10 \text { November } 2020\end{array}$ \\
\hline
\end{tabular}

\section{A B S T R A C T}

An experiment was designed to detect garlic bulb associated viruses through RTPCR and to evaluate the response of genotypes against viruses under field condition. The present study was conducted at Bihar Agricultural University, Sabour, Bhagalpur, Bihar during 2019-20 to study the incidence of bulbassociated Potyviruses in garlic through molecular diagnosis. In order to confirm the presence of virus in stored garlic, RT-PCR based assay was used. The suspected leaves of genotypes were tested for the virus. Majority of genotypes were found positive with potyvirus by producing $300 \mathrm{bp}$ band. Stored garlic bulbs were also tested for the virus and out of 14 genotypes, 8 were found positive with potyvirus. Under field condition, maximum genotypes showed the highest incidence at 90 days after sowing e.g. G-282 with $20.7 \%$ followed by G-1 with $15.0 \%$ disease incidence. Among all the entries, three genotypes, i.e., 499, 516 and 493 showed no any disease symptoms. The present study will be helpful to manage the crop by selecting virus-free garlic. Moreover, timely application of control strategies may be followed based on the field response of disease.

\section{Introduction}

Garlic (Allium sativum L.) is one of the important vegetables in bulb crops. It belongs to family Amaryllidaceae under Asparagales order. Garlic crop is severely affected by several biotic and abiotic stresses. Among the biotic stresses, diseases play a significant role in reducing crop productivity and quality production. The major diseases of garlic in India are downy mildew (Peronospora destructor), purple blotch (Alternaria porri), Stemphylium blight (Stemphylium vesicarium), rust (Puccinia porri), white rot (Sclerotium cepivorum), Botrytis rot (Botrytis porri), bacterial soft rot (Erwinia carotovora pv. carotovora), slippery skin (Burkholderia gladioli pv. allicola), onion yellow dwarf (Onion yellow dwarf virus), leek yellow stripe (Leek yellow stripe virus), garlic mosaic (Garlic mosaic virus) and Iris yellow spot (Iris yellow spot virus). In India, six viruses 
belonging to four different taxonomic groups namely, Allexivirus e.g. Garlic virus X (Garv$X)$ (Baranwal et al., 2011), Potyvirus e.g. Onion yellow dwarf virus (OYDV) (Ghosh and Ahlawat, 1997) and Leek yellow stripe virus (LYSV) (Gupta et al., 2013), Carlavirus e.g. Garlic common latent virus (GarCLV) (Majumder and Baranwal, 2009) and Shallot latent virus (SLV) (Majumder et al., 2008), and Orthotospovirus e.g. Iris yellow spot virus (IYSV) (Gawande et al., 2010) have been found to infect the crop. Mixed viral infections produce mosaic pattern, chlorotic streaking, twisting with curling of leaves and stunting of plants which result in the formation of small bulbs and cloves. Yield loss up to $78 \%$ has been reported due to mixed infection of viruses (Lot et al., 1998; Conci et al., 2003; Lunello et al., 2007).

Among the viral diseases, onion yellow dwarf disease is commonly infecting onion and garlic crops. The virus belongs to the genus Potyvirus under Potyviridae family. The virus is transmitted by aphids (Myzus persicae) in a non-persistent manner. Additionally, the virus is also transmitted by garlic bulbs. The disease has been reported to cause a detrimental effect on the growth of the plants and consequently on bulb production. Moreover, Leek yellow stripe virus (LYSV) is also an important virus of the Potyvirus genus infecting garlic widely and induces severe symptom (Van Dijk, 1993). It causes mosaic and yellow stripes on leaves.

The typical symptoms of yellow streaks, mosaic pattern and stunted growth were observed in garlic varieties at Bihar Agricultural University (BAU), Sabour, Bhagalpur. Considering the emerging issue, an investigation was planned and focussed on molecular detection of potyviruses in garlic genotypes and their response under field condition.

\section{Materials and Methods}

\section{Molecular detection of potyviruses in garlic}

\section{Detection of virus from garlic leaves using RT-PCR}

Suspected leaves from garlic genotypes were collected (432, 352, 498, 305, 516, 417 and 141) from vegetable field of BAU, Sabour. Total RNA of all the samples was extracted using RNeasy RNA Isolation Kit (Qiagen, Germany). One-step reverse transcription PCR (RT-PCR) was performed using Titanium One-Step RT-PCR Kit (Clontech, USA). Additionally, total RNA was also processed for cDNA by using GoScript Reverse Transcription System (Promega, USA) for further investigations. A $25 \mu \mathrm{l}$ reaction was prepared by adding $2.5 \mu \mathrm{l} 10 \mathrm{X}$ one-step buffer, $0.5 \mu \mathrm{l} 50 \mathrm{X}$ dNTP mix, 0.25 $\mu 1 \quad$ recombinant RNase, $12.5 \mu \mathrm{l}$ thermostabilizing reagent, $5 \mu \mathrm{GC}$ melt, 0.5 $\mu$ Oligo (dT) primer, $0.5 \mu \mathrm{l} 50 \mathrm{X}$ Titanium (TaqRT) enzyme, $2.25 \mu \mathrm{l}$ RNase-Free water and $0.5 \mu \mathrm{l}$ forward and reverse primer each along with RNA templates. A set of Potyvirus specific primer oligo 1n TGGTHTGGTGYA THGGARAAYGG and oligo 2n TGGTHT GGTGYATHGGARAAYGG was used in RT-PCR (Marie-Jeanne et al., 2000). The PCR was performed in Surecycler, Agilent, USA programmed with $50^{\circ} \mathrm{C}$ for 60 minutes for cDNA synthesis, $94^{\circ} \mathrm{C}$ for 5 minutes for initial denaturation, $94^{\circ} \mathrm{C}$ for 30 seconds for second denaturation, $49^{\circ} \mathrm{C}$ for 30 seconds for annealing and $68^{\circ} \mathrm{C}$ for 1 minute for extension. After 35 cycles, the final extension was performed at $68^{\circ} \mathrm{C}$ for 2 minutes. The amplified products were analyzed by $1 \%$ agarose gel electrophoresis using gel documentation system, UV Tech Cambridge. Among the positive samples, four were sequenced. 


\section{Detection of virus from garlic bulbs using RT-PCR}

Upon maturity of crop, bulbs were collected from earlier tagged plants (14 genotypes). The harvested bulbs were stored as per the standard procedure. From each lot, five bulb cloves were selected for RNA isolation. Total RNA of all bulb cloves was isolated using SV total RNA Isolation System (Promega, USA). One-step RT-PCR assay was performed as earlier used kit and specific primers.

\section{Field response of different garlic genotypes against viruses}

Response of different garlic genotype against viruses was assessed in natural field condition. A field experiment was designed in randomized block design (RBD) in 3 replications and conducted during winter (Rabi) season of 2019-20 at the Vegetable Research Farm, BAU, Sabour. Each plot was maintained in $4.5 \mathrm{~m} \times 1.5 \mathrm{~m}$ size. Spacing of row to row and plant to plant was $15 \mathrm{~cm}$ and $10 \mathrm{~cm}$ respectively. Under the study, 20 garlic genotypes were screened against viruses. Based on the characteristic symptoms, plants were tagged and the disease incidence was recorded at periodic intervals.

\section{Results and Discussion}

\section{Molecular detection of viruses using RT- PCR in different genotypes}

Garlic plants from all the twenty genotypes showing abnormal mosaic and yellow streaks symptoms and twisting in the leaves (Fig. 2) were collected from the Vegetable Research Farm, BAU, Sabour. Each sample was tested against potyvirus. In each genotype, the collected samples were found positive. The number of positive samples out of total tested plants was detected more in 5 genotypes namely G-1, G-189, G-282, G-323 and G-50 as compared to other genotypes. In G-1, out of 12 tested plants, 7 were found positive. Similarly, 10 out of 14 in G-189, 6 out of 9 in G-282, 7 out of 12 in G-323 and 8 out of 12 in G-50 were found positive (Table 1). The gel electrophoretic profile of RT-PCR product ( 300 bp) of different genotypes was depicted (Fig. 1).

The presence of potyvirus was tested for 14 garlic entries. The virus was detected in 8 out of 14 garlic entries such as Local Garlic Collection-1, G-41, G-282, IC-375416, AC50, AC-283, RUAG and ACC-40. The maximum viral infection $(>10 \%)$ was found in G-41 and the moderate infection (>5-10\%) was observed in Local Garlic Collection-1, IC-375416, AC-283 and ACC-40. The least infection (1-5\%) was shown by G-282, AC-50 and RUAG and among 14 entries, there were 6 entries e.g. BRG-13, BRG-14, AC-200, Yamuna Safed, Godavari and Bhima Purple which did not amplify and showed negative result with Potyvirus specific primer (Table 2).

\section{Field response of different garlic genotypes}

Field response of each genotype against virus was assessed at periodic intervals. It was observed that G-1, G-189, G-282, G-50, 432, 141, BRG-13 and BRG-14 showed disease symptoms appeared after 30 days of sowing. Among them, genotype G-50 showed maximum disease incidence $(6.7 \%)$ on $30^{\text {th }}$ day followed by genotype G-282 (5.3\%). After 45 days of sowing, genotypes G-323, IC-395680 and BRG-10 first showed disease symptoms. Among them, maximum disease incidence was observed for BRG-10 (2.6\%) followed by genotype IC-395680 (1.3\%). The genotypes BRG-8, 498, 305, 417, 352 and BRG-7 showed the delayed disease symptom, i.e., 60 days after sowing. The maximum disease incidence was found in BRG-8 with $2.7 \%$ incidence followed by 352 (2.6\%), 305 
(2.4\%), $417(2.2 \%)$ and 498 (2.0\%). disease incidence. Among all the entries, Maximum genotypes showed the highest three genotypes, i.e., 499, 516 and 493 incidence at 90 days after sowing e.g. G-282 showed no disease symptoms (Table 3). with $20.7 \%$ followed by G-1 with $15.0 \%$

Table.1 Molecular detection of virus using RT-PCR in different genotypes

\begin{tabular}{|c|c|c|}
\hline S.No. & Name of genotypes & $\begin{array}{l}\text { Potyvirus specific primer (No. } \\
\text { positive/Total tested plants) }\end{array}$ \\
\hline 1. & G-1 & $07 / 12$ \\
\hline 2. & G-189 & $10 / 14$ \\
\hline 3. & G-282 & $06 / 09$ \\
\hline 4. & BRG-8 & $03 / 13$ \\
\hline 5. & G-323 & $07 / 12$ \\
\hline 6. & G-50 & $08 / 12$ \\
\hline 7. & 499 & $03 / 10$ \\
\hline 8. & IC-395680 & $05 / 14$ \\
\hline 9. & 498 & $04 / 11$ \\
\hline 10. & 432 & $06 / 14$ \\
\hline 11. & 141 & 03/09 \\
\hline 12. & 516 & $04 / 08$ \\
\hline 13. & 305 & $04 / 09$ \\
\hline 14. & 417 & 03/11 \\
\hline 15. & BRG-10 & $05 / 12$ \\
\hline 16. & 352 & $04 / 12$ \\
\hline 17. & 493 & $04 / 13$ \\
\hline 18. & BRG-7 & 05/11 \\
\hline 19. & BRG -13 & $02 / 12$ \\
\hline 20. & BRG -14 & $03 / 14$ \\
\hline
\end{tabular}


Table.2 Testing of viruses in stored garlic bulbs of different entries harvested from infected crops

\begin{tabular}{|l|l|c|}
\hline S.No. & Name of entries & Infection of Potyvirus \\
\hline $\mathbf{1 .}$ & Local Garlic Collection- 1 & ++ \\
\hline $\mathbf{2 .}$ & BRG-13 & - \\
\hline $\mathbf{3 .}$ & BRG-14 & - \\
\hline $\mathbf{4 .}$ & G-41 & +++ \\
\hline $\mathbf{5 .}$ & G-282 & + \\
\hline $\mathbf{6 .}$ & IC-375416 & ++ \\
\hline $\mathbf{7 .}$ & AC-50 & + \\
\hline $\mathbf{8 .}$ & AC-200 & - \\
\hline $\mathbf{9 .}$ & AC-283 & ++ \\
\hline $\mathbf{1 0}$ & RUAG & + \\
\hline $\mathbf{1 1}$. & Yamuna Safed & - \\
\hline $\mathbf{1 2}$. & Godavari & - \\
\hline $\mathbf{1 3}$. & ACC-40 & ++ \\
\hline $\mathbf{1 4}$ & Bhima Purple & - \\
\hline
\end{tabular}

(-) No amplification, (+) 1-5\% infection, (++) $>5-10 \%$ infection, $(+++)>10 \%$ infection

Table.3 Disease incidence and symptoms of garlic genotypes against viruses

\begin{tabular}{|c|c|c|c|c|c|c|c|}
\hline \multirow[t]{2}{*}{ S.No. } & \multirow[t]{2}{*}{ Genotypes } & \multicolumn{5}{|c|}{$\begin{array}{l}\text { Disease incidence }(\%) \text { in garlic at } \\
\text { periodic intervals }\end{array}$} & \multirow[t]{2}{*}{ Symptom } \\
\hline & & $\begin{array}{c}30 \\
\text { DAS }\end{array}$ & $\begin{array}{c}45 \\
\text { DAS }\end{array}$ & $\begin{array}{c}60 \\
\text { DAS }\end{array}$ & $\begin{array}{c}75 \\
\text { DAS }\end{array}$ & $\begin{array}{c}90 \\
\text { DAS }\end{array}$ & \\
\hline 1. & G-1 & 3.2 & 6.3 & 8.5 & 12.2 & 15.0 & Twisting and mosaic \\
\hline 2. & G-189 & 1.5 & 3.3 & 5.0 & 6.7 & 7.9 & Twisting \\
\hline 3. & G-282 & 5.3 & 12.6 & 17.4 & 18.0 & 20.7 & Twisting and streaking \\
\hline 4. & BRG-8 & 0.0 & 0.0 & 2.7 & 3.1 & 3.6 & Mosaic \\
\hline 5. & G-323 & 0.0 & 1.2 & 1.9 & 2.2 & 3.8 & Twisting \\
\hline 6. & G-50 & 6.7 & 9.0 & 11.3 & 12.5 & 13.3 & Twisting and streaking \\
\hline 7. & 499 & 0.0 & 0.0 & 0.0 & 0.0 & 0.0 & - \\
\hline 8. & IC-395680 & 0.0 & 1.3 & 2.2 & 2.7 & 3.5 & Mosaic \\
\hline 9. & 498 & 0.0 & 0.0 & 2.0 & 2.8 & 3.2 & Mosaic \\
\hline 10. & 432 & 2.2 & 3.7 & 5.0 & 5.9 & 6.5 & Mosaic \\
\hline 11. & 141 & 3.5 & 5.9 & 6.4 & 6.7 & 7.5 & Twisting and mosaic \\
\hline 12. & 516 & 0.0 & 0.0 & 0.0 & 0.0 & 0.0 & - \\
\hline 13. & 305 & 0.0 & 0.0 & 2.4 & 3.5 & 4.4 & Mosaic \\
\hline 14. & 417 & 0.0 & 0.0 & 2.2 & 3.0 & 4.2 & Mosaic \\
\hline 15. & BRG-10 & 0.0 & 2.6 & 4.7 & 6.2 & 7.4 & Yellow streaking \\
\hline 16. & 352 & 0.0 & 0.0 & 2.6 & 3.5 & 4.0 & Mosaic \\
\hline 17. & 493 & 0.0 & 0.0 & 0.0 & 0.0 & 0.0 & - \\
\hline 18. & BRG-7 & 0.0 & 0.0 & 1.4 & 2.7 & 3.7 & Mosaic \\
\hline 19. & BRG-13 & 1.0 & 1.5 & 2.3 & 2.5 & 3.3 & Twisting and streaking \\
\hline 20. & BRG-14 & 1.3 & 2.2 & 2.6 & 2.8 & 3.4 & Twisting and streaking \\
\hline
\end{tabular}

(DAS - Days after sowing) 
Fig.1 Gel electrophoretic profile of RT-PCR product of different genotypes (1) G-1 (2) G-189 (3) G-282 (4) BRG-8 (5) G-323 (6) G-50 (7) 499 (8) IC-395680 (9) 498 (10) 432 (11) 141 (12) 516 (13) 305 (14) 417 (15) BRG-10 (16) 352 (17) 493 (18) BRG-7 (19) BRG-13 (20) BRG-14

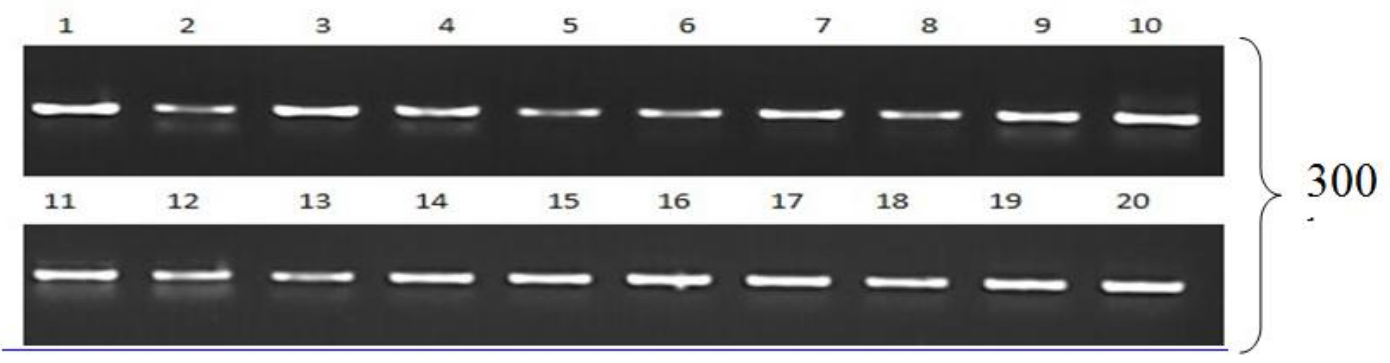

Fig.2 (a) Yellow streaks on leaves (b) Mosaic pattern on leaves (c) Twisting of leaves Testing of viruses in stored garlic bulbs from infected crops

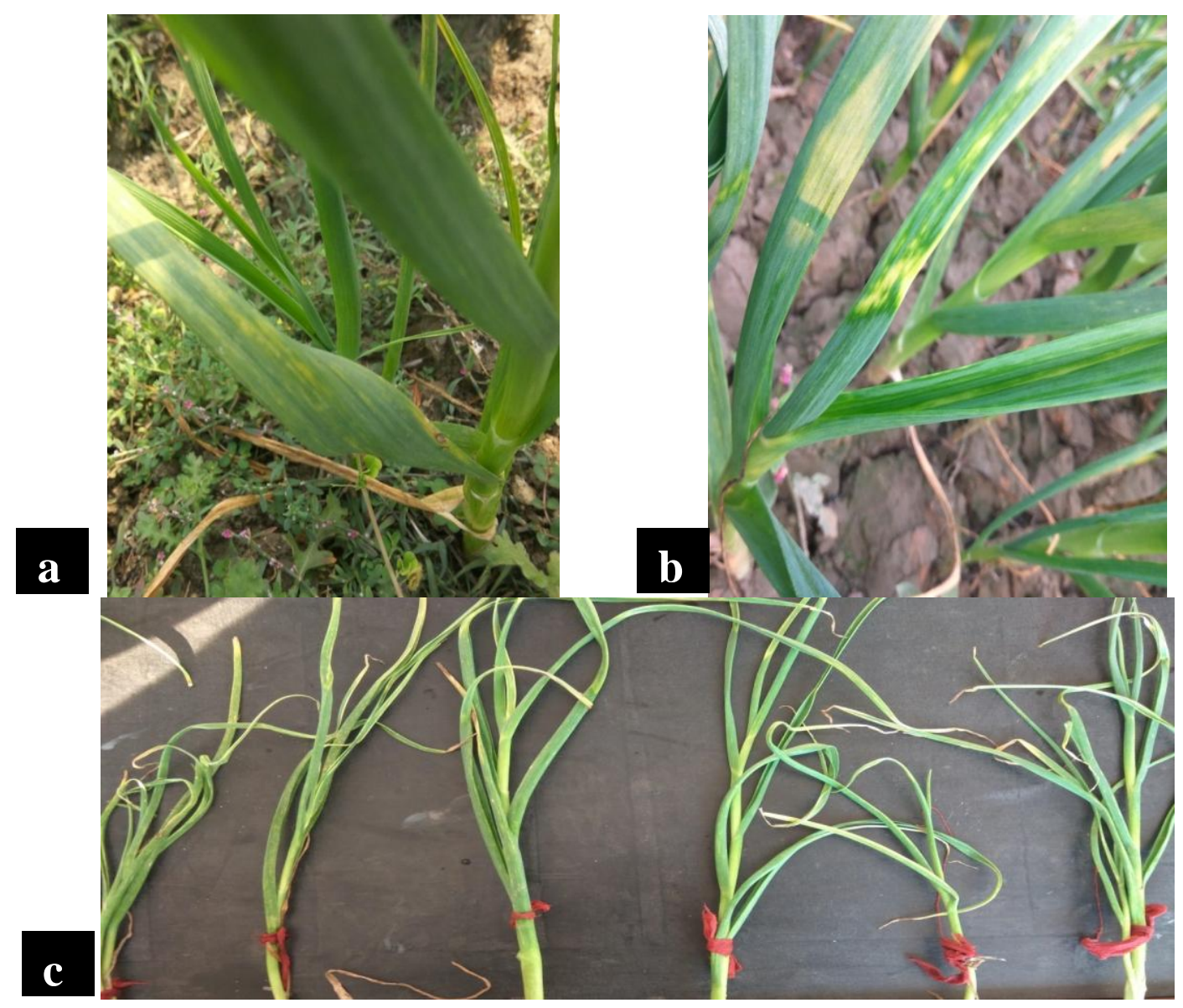

In order to detect the Leek yellow stripe virus (Potyvirus), PCR assay was performed. Various sets of primers were used for PCR to amplify full-length genome of LYSV (Gupta et al., 2017). Development of multiplex RT-
PCR for simultaneous detection of garlic viruses was done by Nam et al., (2015) for the detection of Garlic virus $D$ from garlic plants which showed the yellow stripes, dwarfing and mosaic symptoms. The PCR product was 
sequenced and it showed the maximum identity (91\%) with CP gene of Garlic virus $D$ (Khan et al., 2016). Garlic is commonly grown by bulb which may have the possibility of virus inoculum. Viruses associated with garlic belong to genus Potyvirus which may persist in bulbs and provide the inoculum for subsequent crops. The viruses associated with garlic bulbs under stored conditions were confirmed by RT-PCR (Mann and Minges, 1958). Field response of different genotypes was assessed, most of the entries showed the symptoms with varying degree of aggressiveness. The present study elaborated the RT-PCR based detection in garlic for the association of bulb-associated virus which will encourage for the selection of healthy seed materials. Since, the virus was detected in garlic bulbs, therefore, it will be an important footstep for selection of virus-free garlic stock in garlic cultivation. Based on the field response, few entries or genotypes may be suggested for the resistant breeding programmes.

\section{References}

Baranwal, V.K., Singh, P. and Jain, R.K. (2011). First report of Garlic virus $X$ infecting garlic in India. Plant Disease., 95:1197.

Conci, V.C., Canavelli, A. and Lunello, P. (2003). Yield losses associated with virus-infected garlic plants during five successive years. Plant Disease., 87:1411-1415.

Gawande, S.J., Khar, A. and Lawande, K.E. (2010). First report of Iris yellow spot virus on garlic in India. Plant Disease., 94:1066.

Ghosh, D.K. and Ahlawat, Y.S. (1997). Filamentous viruses associated with the mosaic disease of garlic in India. Indian Phytopathology., 50: 266-267.

Gupta, N., Jain, R.K., Rao, G.P. and Baranwal, V.K. (2017). Molecular characterization and phylogenetic analysis of coat protein gene of Leek yellow stripe virus infecting garlic in India. Indian Phytopathology., 70(1): 114-121.

Gupta, N., Prabha, K., Islam, S. and Baranwal, V.K. (2013). First report of Leek yellow stripe virus in India from garlic. Journal of Plant Pathology., 95: 69-77.

Khan, I., Sharma, A., Kang, S.S., Kaur, G. and Dhatt, A.S. (2016). Molecular characterization and identification of garlic virus $\mathrm{d}$ associated with garlic in India. Journal of Plant Pathology., 607609.

Lot, H., Chovelon, V., Souche, S. and Delecolle, B. (1998). Effects of Onion yellow dwarf and Leek yellow stripe viruses on symptomatology and yield loss of three French garlic cultivars. Plant Disease., 82:1381-1385.

Lunello, P., Di Rienzo, J. and Conci, V. (2007). Yield loss in garlic caused by Leek yellow stripe virus Agrentinean isolate. Plant Disease., 91:153-158.

Majumder, S. and Baranwal, V.K. (2009). First report of Garlic common latent virus in Garlic from India. Plant Disease., 93: 106-106.

Majumder, S., Baranwal, V.K. and Joshi, S. (2008). Simultaneous detection of onion yellow dwarf virus and shallot latent virus in infected leaves and cloves of garlic by duplex RT-PCR. Journal of Plant Pathology., 90(2):371-374.

Mann, L.K. and Minges, P.A. (1958). Growth and bulbing of garlic (Allium sativum L.) in response to storage temperature of planting day length and planting date. Hilgardia., 27:385-419.

Marie-Jeanne, V., Ioos, R., Peyre, J., Alliot, B. and Signoret, P. (2000). Differentiation of Poaceae Potyviruses by Reverse Transcription Polymerase Chain Reaction and Restriction 
Analysis. J. Phytopatholology., 148:141-151.

Nam, M., Lee, Y.H., Park, C.Y., Lee, M.A., Bae, Y.S., Lim, S. and Lee, S.H. (2015). Development of multiplex RT-PCR for simultaneous detection of garlic viruses and the incidence of garlic viral disease in garlic genetic resources. Journal of Plant Pathology., 31(1): 90.

Van Dijk, P. (1993). Survey and characterization of Potyviruses and their strains of Allium species. Netherlands Journal of Plant Pathology., 99: 1-48.

\section{How to cite this article:}

Kumar Aditya, A.P. Bhagat, Sangeeta Shree and Mohammad Ansar. 2020. Molecular Detection of Bulb-Associated Potyviruses in Garlic and Their Field Response. Int.J.Curr.Microbiol.App.Sci. 9(11): 1938-1945. doi: https://doi.org/10.20546/ijcmas.2020.911.229 